University of Warwick institutional repository: http://go.warwick.ac.uk/wrap This paper is made available online in accordance with publisher policies. Please scroll down to view the document itself. Please refer to the repository record for this item and our policy information available from the repository home page for further information.

To see the final version of this paper please visit the publisher's website. Access to the published version may require a subscription.

Author(s): C. RAHN, A. MEAD, A. DRAYCOTT, R. LILLYWHITE and T. SALO

Article Title: A sensitivity analysis of the prediction of the nitrogen fertilizer requirement of cauliflower crops using the HRI WELL_N computer model

Year of publication: 2001

Link to published version:

http://dx.doi.org/10.1017/S0021859601001174

Publisher statement: None 


\title{
A sensitivity analysis of the prediction of the nitrogen fertilizer requirement of cauliflower crops using the HRI WELL_N computer model
}

\author{
C. RAHN ${ }^{1 *}$, A. MEAD ${ }^{2}$, A. DRAYCOTT ${ }^{1}$, R. LILLYWHITE ${ }^{1}$ AND T. SALO ${ }^{3}$ \\ ${ }^{1}$ Department of Soil and Environment Sciences, Horticulture Research International, Wellesbourne, \\ Warwick CV35 9EF, UK \\ ${ }^{2}$ Biometrics Department, Horticulture Research International, Wellesbourne, Warwick, CV35 9EF, UK \\ ${ }^{3}$ Department of Crops and Soil, Agricultural Research Centre of Finland, 31600 Jokionen, Finland
}

(Revised MS received 2 April 2001)

\begin{abstract}
SUMMARY
HRI WELL_N is an easy to use computer model, which has been used by farmers and growers since 1994 to predict crop nitrogen $(\mathrm{N})$ requirements for a wide range of agricultural and horticultural crops.

A sensitivity analysis was carried out to investigate the model predictions of the $\mathrm{N}$ fertilizer requirement of cauliflower crops, and, at that rate, the yield achieved, yield response to the fertilizer applied, $\mathrm{N}$ uptake, $\mathrm{NO}_{3}-\mathrm{N}$ leaching below 30 and $90 \mathrm{~cm}$ and mineral $\mathrm{N}$ at harvest. The sensitivity to four input factors - soil mineral $\mathrm{N}$ before planting, mineralization rate of soil organic matter, expected yield and duration of growth - was assessed. Values of these were chosen to cover ranges between $40 \%$ and $160 \%$ of values typical for field crops of cauliflowers grown in East Anglia. The assessments were made for three soils - sand, sandy loam and silt - and three rainfall scenarios - an average year and years with $144 \%$ or $56 \%$ of average rainfall during the growing season. The sensitivity of each output variable to each of the input factors (and interactions between them) was assessed using a unique 'sequential' analysis of variance approach developed as part of this research project.

The most significant factors affecting $\mathrm{N}$ fertilizer requirement across all soil types/rainfall amounts were soil mineral $\mathrm{N}$ before planting and expected yield. $\mathrm{N}$ requirement increased with increasing yield expectation, and decreased with increasing amounts of soil mineral $\mathrm{N}$ before planting. The responses to soil mineral $\mathrm{N}$ were much greater when higher yields were expected. Retention of $\mathrm{N}$ in the rooting zone was predicted to be poor on light soils in the wettest conditions suggesting that to maximize $\mathrm{N}$ use, plants needed to grow rapidly and have reasonable yield potential.

Assessment of the potential impacts of errors in the values of the input factors indicated that poor estimation of, in particular, yield expectation and soil mineral $\mathrm{N}$ before planting could lead to either yield loss or an increased level of potentially leachable soil mineral $\mathrm{N}$ at harvest.

The research demonstrates the benefits of using computer simulation models to quantify the main factors for which information is needed in order to provide robust $\mathrm{N}$ fertilizer recommendations.
\end{abstract}

\section{INTRODUCTION}

With around $750000 \mathrm{t}$ of nitrogen $(\mathrm{N})$ being applied to tilled crops in England and Wales, it is important to optimize its application. Excessive amounts of fertilizer $\mathrm{N}$ can reduce the quality and harvestability

\footnotetext{
* To whom all correspondence should be addressed. Email: Clive.rahn@hri.ac.uk
}

of crops, it can cause cereal crops to lodge, increase susceptibility to disease (Everaarts 1994), and reduce the storability of produce, as well as increasing the risk of nitrate leaching. Thus, in order to allow the environmental sustainability of both arable and horticultural crops, there is a great need to maximize the efficiency of $\mathrm{N}$ use and match it to $\mathrm{N}$ demand.

Many approaches for the estimation of fertilizer requirements are available. These include past experience, the application of the same amount of $\mathrm{N}$ to 
all fields, the use of simple tables, or calculations using measurements of soil mineral N. Decisions based on past experience, however, can be rather subjective and this approach may not always lead to sound decision making. There is always the temptation to apply additional $\mathrm{N}$ if early growth is poor, but the growth limiting factors may be poor soil structure, soil moisture, pest or disease problems rather than lack of $\mathrm{N}$.

Systems based on a single fertilizer rate specific for each for all crops may produce satisfactory yields (Neeteson et al. 1987), but over-fertilization on some sites can give rise to nitrate leaching and increase the risk of variable produce quality. An improvement is to use simple tables, such as those provided in National fertilizer recommendations (MAFF 2000), which take account of previous cropping history, overwinter rainfall, and soil type to generate a 'soil nitrogen supply index'. However, in high residue situations, where large applications of manure have been applied (Shepherd 1993), or in intensive brassica rotations (Rahn et al. 1993, 1996b), timely measurements of soil mineral $\mathrm{N}$ allow more balanced fertilizer predictions to be made. Fertilizer recommendation systems, such as the 'KNS' system (Lorenz et al. 1989), provide a more comprehensive approach to fertilizer advice for field vegetable crops. They do, however, rely on the ability to record more than one measurement of soil mineral $\mathrm{N}$ during crop growth, in order to take account of the release of $\mathrm{N}$ from crop residues and loss of $\mathrm{N}$ by leaching. They also require that irrigation is available to support the late applications of $\mathrm{N}$ fertilizer. Another approach for field vegetables is provided by computer 'expert' systems, such as ' $\mathrm{N}$ Expert'. This system predicts the amounts of $\mathrm{N}$ available from crop residues and soil organic matter (Fink \& Scharpf 1993), reducing the need for repeat measurements of soil mineral N.

Further improvement to the accuracy of the prediction of fertilizer requirements, however, requires an understanding of the effects of many interacting factors. Computer simulation models can be built to incorporate the effects of many factors - previous crop residues, the release rate of $\mathrm{N}$ from soil organic matter, soil type, crop demand, rooting depth, planting and harvest dates - and the interactions between them. Information on expected rainfall and temperature then allows such models to provide improved predictions of fertilizer requirements and hence optimize the use of available fertilizer inputs. One of the potential benefits of using good models to provide fertilizer recommendations is the provision of consistent and quantifiable advice. However, the usefulness of any model depends on the accuracy with which the input values can be measured or estimated.

The purpose of this paper is to briefly describe the WELL_N fertilizer prediction model, and to examine the sensitivity of its predictions for cauliflower crops with variability in a number of key inputs, including soil and meteorological factors. Cauliflowers are chosen as they have a large $\mathrm{N}$ requirement (up to $250 \mathrm{~kg} / \mathrm{ha}$ ) and because the penalties for failing to meet market criteria are so large that it is critical to predict fertilizer requirement accurately.

The results from this sensitivity analysis will identify those input variables on which the precision of any fertilizer recommendations is most dependent, and that have the greatest impact on yield and in reducing the risks of nitrate leaching.

\section{MATERIALS AND METHODS}

\section{Model description and derivation}

Over a number of years a dynamic simulation model for the prediction of $\mathrm{N}$ fertilizer requirements has been developed for a wide range of horticultural, and some arable crops. The research model upon which WELL_N is based has been described by Greenwood et al. (1996). The derivation and testing of the important functions in the model have been given in a series of papers - on growth rate and $\mathrm{N}$ concentration (Greenwood et al. 1986, 1990, 1991), root development (Greenwood et al. 1982), apparent fertilizer recovery (Greenwood et al. 1989) and

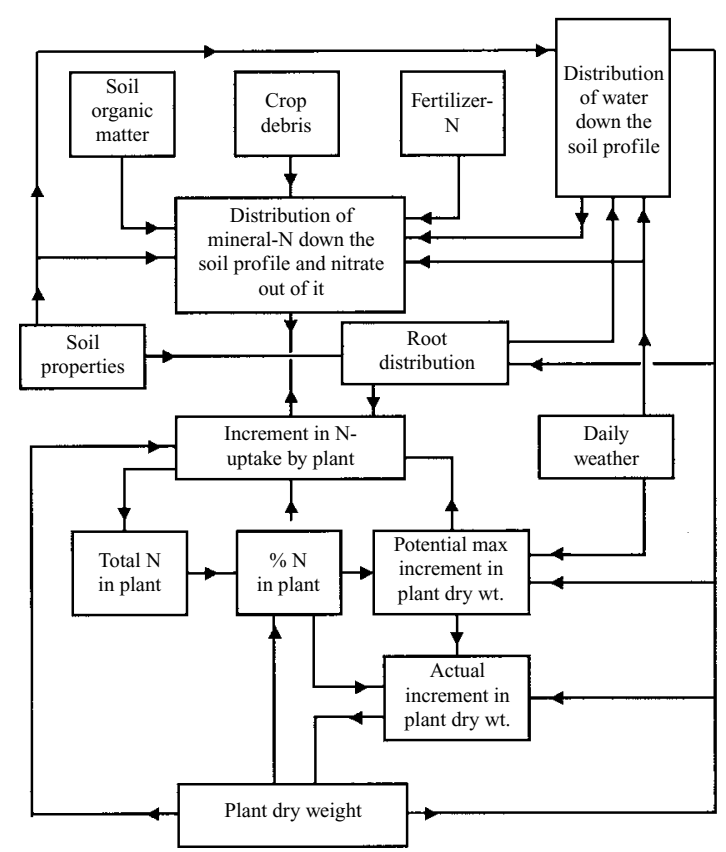

Fig. 1. The structure of the research model upon which WELL_N is based. 
Table 1. Required input data for $W E L L \_N$ for this sensitivity analysis

\begin{tabular}{|c|c|c|}
\hline Information & Data & Derived from \\
\hline Meteorological & $\begin{array}{l}\text { Mean air temperature }\left({ }^{\circ} \mathrm{C}\right) \text {, rainfall, and } \\
\text { evaporation from open water }(\mathrm{mm} / \text { day })\end{array}$ & Weather data sets for $1982,1990,1992$ \\
\hline \multirow[t]{2}{*}{ Soil } & Water content at field capacity $(\mathrm{ml} / \mathrm{ml})$ & $\begin{array}{l}0 \cdot 20,0 \cdot 26,0 \cdot 38 \text { for sand, sandy loam and } \\
\text { silt loam soils respectively }\end{array}$ \\
\hline & Barriers to rooting - depth $(\mathrm{cm})$ & No limit to rooting depth \\
\hline Crop residues & $\begin{array}{l}\% \mathrm{~N} \text {, dry wt } \mathrm{t} / \mathrm{ha}, \mathrm{C}: \mathrm{N} \text { and date of } \\
\text { incorporation }\end{array}$ & No previous crop residue incorporated \\
\hline \multirow[t]{5}{*}{ Cauliflower crop } & Time of planting (date) & April 15 \\
\hline & Weight at planting $(\mathrm{kg} / \mathrm{ha})$ & $30 \mathrm{~kg} / \mathrm{ha}$ \\
\hline & $\% \mathrm{~N}$ at planting & $\begin{array}{l}\text { Internal model calculation based on } \\
\text { Greenwood et al. (1996) }\end{array}$ \\
\hline & Duration of growth (days) & See Table 2 \\
\hline & Dry wt at harvest (t/ha) & See Table 2 \\
\hline Soil moisture deficit & Date (days), SMD (mm) & $0 \mathrm{~mm}$ on 1 November \\
\hline Soil mineral $\mathrm{N}$ & $\begin{array}{l}\text { Layer size, number of layers, mineral } \mathrm{N} \\
\text { content in each layer }\end{array}$ & $\begin{array}{l}30 \mathrm{~cm} \text { layer size, } 3 \text { layers; Mineral } \mathrm{N} \\
\text { distributed evenly to } 90 \mathrm{~cm} \text { depth on } \\
1 \text { April }\end{array}$ \\
\hline
\end{tabular}

leaching (Burns 1974). Versions of the whole model have been tested for potato (Neeteson et al. 1987), wheat (Greenwood et al. 1987), onion (Greenwood et al. 1992), and cabbage (Riley \& Guttormsen 1993, $1994)$ and for a wide range of different arable and vegetable crops (Greenwood \& Draycott 1989). The model has also been tested on a four-crop rotation containing cauliflower crops (Greenwood et al. 1996). The model has been 'commercially' tested by a number of farm consultants and growers (Burns et al. 1997).

WELL_N is currently available to run on IBMcompatible PCs and has been extended to include user-friendly input and output to encourage farmers, growers and their advisors to use it. The structure of the model is shown in Fig. 1, and calculations are performed on a daily time-step.

The inputs required for running the model are shown in Table 1. The model can provide recommendations for 25 crops. Having selected a crop, details of the intended fertilizer application method (top or base dressing) and the date of fertilizer application are required. The date of drilling or transplanting, duration of growth, and expected yield must also be provided. The assessment of prospective yield should be based on previous experience of marketable yields in the area. However, totally unrealistic yields will not be simulated if there is not enough $\mathrm{N}$ in the soil profile to support growth. Where data from previous crops are not available, suitable default values are used. Soil moisture deficit values are then required, the simplest approach being to use a value of zero at the date when drains begin to flow on non-cracking soils. A single measurement of soil mineral $\mathrm{N}$, usually determined before planting, is required to initiate the model. This would normally be provided to at least $60 \mathrm{~cm}$ for cauliflower crops. Additional information, collected during crop growth, can be used to further improve crop management by checking the need for any topdressings of $\mathrm{N}$ fertilizer. This might include details of rainfall, temperature, evaporation, irrigation, soil mineral $\mathrm{N}$, soil moisture deficit, crop size and $\mathrm{N}$ content.

Outputs from the model include predictions of marketable fresh weight, total dry weight, the $\mathrm{N}$ content of the crop residues and the soil mineral $\mathrm{N}$ remaining at harvest, at a range of levels of applied fertilizer $\mathrm{N}$. The recommended application level, taken as the level above which no increase in marketable yield is achieved, is highlighted, though in practice this optimum value is difficult to establish (Sutherland et al. 1986). Predicted values of the $\mathrm{N}$ content of crop residues and soil mineral $\mathrm{N}$ at harvest provide estimates of potentially leachable $\mathrm{NO}_{3}-\mathrm{N}$ over the winter. The model also provides an estimate of leaching losses since the soil attained field capacity the previous autumn.

\section{Design of simulation study}

In designing a simulation study to characterize the uncertainty in input variables to the WELL_N model, a number of approaches are possible. Where there are a large number of input variables, a common approach 
Table 2. Key input variables, and the settings of these variables used in the sensitivity analysis

\begin{tabular}{|c|c|}
\hline Input factor & Factor levels \\
\hline Soil type & Sand, sandy loam, silt loam \\
\hline Rainfall & Low, average, high \\
\hline $\begin{array}{l}\text { Marketable yield } \\
\text { (t/ha fresh weight) }\end{array}$ & $20,25,30,35,40,45,50$ \\
\hline $\begin{array}{l}\text { Duration of growth } \\
\text { from } 15 \text { April (days) }\end{array}$ & $56,70,84,98,112,126,140$ \\
\hline $\begin{array}{l}* \text { Soil mineral } \mathrm{N} \text { on } \\
1 \text { April }(0-90 \mathrm{~cm})\end{array}$ & $60,90,120, \mathbf{1 5 0}, 180,210,240$ \\
\hline $\begin{array}{l}\text { Net mineralization rate } \\
\left(\mathrm{kg} / \mathrm{ha} / \text { day } @ 15.9{ }^{\circ} \mathrm{C}\right)\end{array}$ & $\begin{array}{l}0 \cdot 28,0 \cdot 42,0 \cdot 56, \mathbf{0} \cdot 7,0 \cdot 84 \\
0 \cdot 98,1 \cdot 12\end{array}$ \\
\hline
\end{tabular}

Bold values are typical for crops in intensive horticultural rotations.

* Mineral $\mathrm{N}$ distributed evenly to $90 \mathrm{~cm}$ depth.

is to use Monte Carlo sampling to generate a distribution for the output variable(s) based on random samples drawn from the assumed distributions for the input variables. An improved coverage of the input variable space can be achieved by using Latin Hypercube Sampling (McKay et al. 1979), in which a stratified sample is taken for each input variable, ensuring that the achieved sample covers the full range of possible values for each input variable. Whilst these approaches should allow some assessment of the individual importance of each input variable, the independent assessment of both the main effects of input variables and the interactions between them can only be achieved by considering a set of factorial combinations for fixed levels of each input variable. The choice of whether to assess the complete set of factorial combinations or some fractional set depends on the number of input variables of interest, and the number of levels for each variable. To screen a large number of variables, only two or three levels of each factor might be considered, and with sufficient variables it is probably sensible to consider assessing a relatively small fraction of the complete factorial set.

For this study, prior knowledge of the model indicated that there were six key input variables (Table 2). An assessment of the importance of the main effects and interactions between these variables could be achieved by considering all factorial combinations of only two or three levels for each variable. However, a better impression of the shape of the response surfaces could be obtained by considering more levels for each variable, and the cost of assessing the increased number of combinations was small. Thus it was decided to consider all combinations of the four quantitative variables each at seven different levels, within each combination of three soil types and three rainfall levels (Table 2). A modified version of the WELL_N model was used in this study, allowing multiple runs of the model for all factorial combinations of the four quantitative variables.

Soil types were chosen to represent a range of soils with respect to the leaching of $\mathrm{N}$ : sandy, sandy loam and silt loam, which had water holding capacities at field capacity of $0 \cdot 20$ (leaky), $0 \cdot 26$ and 0.38 (retentive) $\mathrm{ml} / \mathrm{ml}$ of soil respectively. The three meteorological data sets were selected from the 37 years available for Wellesbourne. One represented a year with an average level of spring and summer rainfall (1982 with $287 \mathrm{~mm}$ rainfall between April and September), and the second and third represented seasons with higher (1992 with $144 \%$ of the average) and lower rainfall (1990 with $56 \%$ of the average) respectively. The corresponding temperature data were used, with average temperatures of $11.96,11.80$ and $11.43^{\circ} \mathrm{C}$ for the low, average and high rainfall data sets respectively. The central values of marketable yield, duration of growth, soil mineral $\mathrm{N}$ before planting, and mineralization rate (Table 2) were chosen to represent typical levels for field crops of cauliflower grown in East Anglia. A range of values representing between $40 \%$ and $160 \%$ of the central values were chosen covering expected variations in practice.

Other input data with fixed values included: the date when soil moisture deficit was set to 0 (1 November in the previous winter), and the cauliflower crops planting date (15 April). The land was taken to be fallow in the previous year. Soil mineral $\mathrm{N}$ was taken to have been measured on 1 April and the amounts shown in Table 2 were distributed uniformly to $90 \mathrm{~cm}$.

For each combination of input factors, results were simulated at 15 different applied $\mathrm{N}$ fertilizer levels, ranging from 0 to $560 \mathrm{~kg} / \mathrm{ha}$ in steps of $40 \mathrm{~kg} / \mathrm{ha}$. Predictions of marketable yield, N uptake, soil mineral $\mathrm{N}$ at harvest to both 30 and $90 \mathrm{~cm}$ depths, and leaching below both 30 and $90 \mathrm{~cm}$, between planting date and harvest date, were made for each of the levels of applied fertilizer. The optimum applied fertilizer level was defined to be that producing $99 \%$ of the maximum yield. For each combination of the levels of the input variables, this value was estimated by inverse cubic interpolation (Johnson \& Riess 1982; Genstat 5 Committee 1993) of the simulated yield values, thus avoiding the assumption of any particular parametric form of response curve. Appropriate values of the following variables were then estimated by cubic interpolation at this optimum applied fertilizer level:

(1) Achieved yield.

(2) N uptake by the crop.

(3) Soil mineral $\mathrm{N}$ at harvest to $30 \mathrm{~cm}$ and $90 \mathrm{~cm}$.

(4) Nitrate-N leached below $30 \mathrm{~cm}$ and below $90 \mathrm{~cm}$ during growing season. 
Table 3. Summary of sequential analysis for applied fertilizer $N$ to achieve $99 \%$ of maximum yield for average rainfall and sandy loam

\begin{tabular}{|c|c|c|c|c|c|c|c|c|}
\hline \multirow[b]{2}{*}{ Treatment term } & \multicolumn{3}{|c|}{ Treatment } & \multicolumn{3}{|c|}{ Residual } & \multirow{2}{*}{$\begin{array}{l}\text { Variance } \\
\text { ratio }\end{array}$} & \multirow[b]{2}{*}{ F-probability } \\
\hline & D.F. & SS & MS & D.F. & SS & MS & & \\
\hline Soil mineral N (S) & 6 & 3489080 & $581513 \cdot 3$ & 2394 & 6528331 & $2627 \cdot 0$ & $213 \cdot 246$ & $<0.001$ \\
\hline Mineralization rate $(\mathrm{M})$ & 6 & 1228374 & $204729 \cdot 0$ & 2394 & 8789036 & $3671 \cdot 3$ & $55 \cdot 765$ & $<0 \cdot 001$ \\
\hline Harvest yield (Y) & 6 & 4331617 & $710936 \cdot 1$ & 2394 & 5685794 & $2375 \cdot 0$ & $303 \cdot 971$ & $<0 \cdot 001$ \\
\hline Duration of growth (D) & 6 & 608118 & $101353 \cdot 0$ & 2394 & 9409293 & $3930 \cdot 4$ & $25 \cdot 787$ & $<0.001$ \\
\hline \multicolumn{9}{|l|}{ Two-factor interactions } \\
\hline S.M & 36 & 2296 & $63 \cdot 8$ & 2352 & 5297660 & $2252 \cdot 4$ & $0 \cdot 028$ & $1 \cdot 000$ \\
\hline S.Y & 36 & 215478 & $5985 \cdot 5$ & 2352 & 1981236 & $842 \cdot 4$ & $7 \cdot 106$ & $<0.001$ \\
\hline M.Y & 36 & 4941 & $137 \cdot 3$ & 2352 & 4452478 & $1893 \cdot 1$ & 0.073 & $1 \cdot 000$ \\
\hline S.D & 36 & 624 & $17 \cdot 3$ & 2352 & 5919588 & $2516 \cdot 8$ & $0 \cdot 007$ & 1.000 \\
\hline M.D & 36 & 103936 & $2887 \cdot 1$ & 2352 & 8076982 & $3434 \cdot 1$ & $0 \cdot 841$ & 0.737 \\
\hline Y.D & 36 & 18055 & $501 \cdot 5$ & 2352 & 5059621 & $2151 \cdot 2$ & $0 \cdot 233$ & $1 \cdot 000$ \\
\hline \multicolumn{9}{|l|}{ Three-factor interactions } \\
\hline S.M.Y & 216 & 981 & $5 \cdot 4$ & 2058 & 744643 & $361 \cdot 8$ & $0 \cdot 013$ & $1 \cdot 000$ \\
\hline S.M.D & 216 & 1697 & 7.9 & 2058 & 4583284 & $22271 \cdot 1$ & $0 \cdot 004$ & 1.000 \\
\hline S.Y.D & 216 & 906 & $4 \cdot 2$ & 2058 & 1353533 & $657 \cdot 7$ & $0 \cdot 006$ & $1 \cdot 000$ \\
\hline M.Y.D & 216 & 1497 & 6.9 & 2058 & 3720872 & $1808 \cdot 0$ & 0.004 & $1 \cdot 000$ \\
\hline \multicolumn{9}{|l|}{ Four-factor interactions } \\
\hline S.M.Y.D & 1296 & 9810 & $7 \cdot 6$ & 0 & 0 & * & $*$ & * \\
\hline
\end{tabular}

* Indicates that no ratio could be calculated as the mean square for the denominator was zero.

The output variables were selected because they were of agronomic significance (achieved yield and applied $\mathrm{N}$ ) or environmental significance (leached $\mathrm{NO}_{3}-\mathrm{N}$ and soil mineral $\mathrm{N}$ at harvest (i.e. potential for leaching)), or linked these two aspects ( $\mathrm{N}$ uptake).

\section{Statistical methods}

In order to identify the factors, and interactions between factors, to which the simulation model was most sensitive, the predicted responses within each soil type-weather combination were subjected to analysis of variance using Genstat 5 (Genstat 5 Committee 1993). As there was no underlying residual term with which to compare the effect of each main effect or interaction term, a sequential approach, based on the concept of stepwise regression (Sokal \& Rohlf 1995), was developed. This approach identifies the more important effects, avoiding the spurious significance levels that would be indicated by using the more conventional approach of using high-order interactions as an estimate of error against which treatment effects are tested. The factorial structure of explanatory variables was maintained so that higher order interactions were only considered after all associated lower order terms. For each main effect, or interaction term, a variance ratio was constructed to compare the mean square due to the term with the variance due to unrelated terms (effectively the variability about the fitted term). So, for main effects the denominator of the variance ratio was the sum of the sums of squares for all other terms (main effects, two-, three- and four-factor interactions) divided by the sum of the degrees of freedom for these terms. The residual degrees of freedom for main effects are simply obtained by subtracting the main effect degrees of freedom (6) from the total degrees of freedom (2400) to get 2394. Similarly, for two-factor interactions, the denominator of the variance ratio was the sum of the sums of squares for all unrelated terms (the other two main effects, all other two-factor interactions and the three- and four-factor interactions) divided by the equivalent sum of degrees of freedom. Calculation of the residual degrees of freedom for each two-factor interaction involves subtracting both the interaction degrees of freedom (36) and the degrees of freedom for both associated main effects $(6+6)$ from the total degrees of freedom to get 2352 . The denominator for variance ratios for three-factor interaction terms similarly excluded the variability due to the three associated main effects and three associated two-factor interactions. The residual degrees of freedom for each three-factor interaction is obtained by subtracting the interaction degrees of freedom (216), the degrees of freedom for each of the three associated two-factor interactions $(36+36+36)$, and the degrees of freedom for each of the associated main effects $(6+6+6)$ from the total degrees of freedom to get 2058. An example analysis summary is 
Table 4. Variance ratios for all main effects and statistically significant interactions - relevant degrees of freedom are given in Table 3

\begin{tabular}{|c|c|c|c|c|c|c|c|c|c|}
\hline $\begin{array}{l}\text { Rainfall } \\
\text { Soil type } \\
\text { Treatment term }\end{array}$ & $\begin{array}{l}\text { Low } \\
\text { Sand }\end{array}$ & $\begin{array}{c}\text { Low } \\
\text { Sandy loam }\end{array}$ & $\begin{array}{l}\text { Low } \\
\text { Silt loam }\end{array}$ & $\begin{array}{l}\text { Average } \\
\text { Sand }\end{array}$ & $\begin{array}{c}\text { Average } \\
\text { Sandy loam }\end{array}$ & $\begin{array}{l}\text { Average } \\
\text { Silt loam }\end{array}$ & $\begin{array}{l}\text { High } \\
\text { Sand }\end{array}$ & $\begin{array}{c}\text { High } \\
\text { Sandy loam }\end{array}$ & $\begin{array}{l}\text { High } \\
\text { Silt loam }\end{array}$ \\
\hline \multicolumn{10}{|c|}{ (a) $\mathrm{N}$ requirement to achieve $99 \%$ of maximum yield } \\
\hline Soil mineral N (S) & 211 & 209 & 209 & 213 & 213 & 214 & 189 & 194 & 200 \\
\hline Mineralization rate $(\mathrm{M})$ & $50 \cdot 3$ & $51 \cdot 6$ & $51 \cdot 6$ & 53.6 & $\mathbf{5 5} \cdot 8$ & $\mathbf{5 5 \cdot 7}$ & $69 \cdot 8$ & $62 \cdot 0$ & $59 \cdot 6$ \\
\hline Harvest yield $(\mathrm{Y})$ & 308 & 304 & 304 & 311 & 304 & 303 & 314 & 328 & 321 \\
\hline Duration of growth (D) & $31 \cdot 8$ & $31 \cdot 9$ & $31 \cdot 8$ & $26 \cdot 7$ & $25 \cdot 8$ & $25 \cdot 5$ & $21 \cdot 8$ & $20 \cdot 8$ & $22 \cdot 6$ \\
\hline S.Y interaction & 3.04 & $6 \cdot 85$ & 6.96 & $6 \cdot 06$ & $7 \cdot 11$ & $7 \cdot 31$ & $6 \cdot 34$ & $7 \cdot 96$ & $7 \cdot 79$ \\
\hline \multicolumn{10}{|c|}{ (b) Yield response ( $\mathrm{t} / \mathrm{ha})$ : difference in response for $\mathrm{N}$ fertilizer applied at recommended rate and zero applied $\mathrm{N}$} \\
\hline Soil mineral N (S) & 145 & 130 & 128 & 146 & 133 & 131 & $96 \cdot 3$ & 108 & 117 \\
\hline Mineralization rate $(\mathrm{M})$ & $47 \cdot 6$ & $54 \cdot 2$ & $\mathbf{5 7 \cdot 0}$ & $51 \cdot 3$ & $\mathbf{5 8 \cdot 7}$ & $62 \cdot 1$ & $55 \cdot 6$ & $64 \cdot 6$ & $67 \cdot 7$ \\
\hline Harvest yield $(\mathrm{Y})$ & 394 & 410 & 407 & 404 & 415 & 412 & 607 & 496 & 450 \\
\hline Duration of growth (D) & $38 \cdot 0$ & $35 \cdot 8$ & 35.9 & $32 \cdot 5$ & $30 \cdot 3$ & $29 \cdot 4$ & $18 \cdot 4$ & $22 \cdot 1$ & 23.9 \\
\hline S.Y interaction & 3.09 & 5.90 & $5 \cdot 81$ & $6 \cdot 27$ & $6 \cdot 16$ & $6 \cdot 08$ & $5 \cdot 46$ & 5.89 & 5.96 \\
\hline M.Y interaction & $1 \cdot 06$ & $1 \cdot 21$ & $1 \cdot 23$ & $1 \cdot 18$ & $1 \cdot 31$ & $1 \cdot 33$ & 1.76 & $1 \cdot 71$ & 1.58 \\
\hline \multicolumn{10}{|c|}{ (c) $\mathrm{N}$ leaching below $90 \mathrm{~cm}$ where $\mathrm{N}$ applied at recommended rate } \\
\hline Soil mineral N (S) & $*$ & $*$ & $*$ & $*$ & $*$ & * & 454 & 147 & $93 \cdot 7$ \\
\hline Mineralization rate $(\mathrm{M})$ & $*$ & $*$ & * & * & $*$ & * & $0 \cdot 00$ & $0 \cdot 00$ & $0 \cdot 00$ \\
\hline Harvest yield $(\mathrm{Y})$ & $*$ & $*$ & * & * & $*$ & * & $5 \cdot 44$ & $14 \cdot 7$ & $25 \cdot 0$ \\
\hline Duration of growth (D) & $*$ & $*$ & $*$ & $*$ & $*$ & $*$ & 146 & 431 & 493 \\
\hline S.D interaction & $*$ & $*$ & * & $*$ & $*$ & * & $17 \cdot 8$ & 41.6 & $34 \cdot 0$ \\
\hline Y.D interaction & $*$ & $*$ & $*$ & $*$ & $*$ & $*$ & $13 \cdot 4$ & $13 \cdot 5$ & 18.9 \\
\hline S.Y.D interaction & $*$ & $*$ & * & $*$ & $*$ & * & 16958 & 9311 & 37837 \\
\hline
\end{tabular}


(d) $\mathrm{N}$ leaching below $30 \mathrm{~cm}$ where $\mathrm{N}$ applied at recommended rate Soil mineral N (S)

Mineralization rate $(\mathrm{M})$

Harvest yield (Y)

Duration of growth (D)

S.D interaction

M.D interaction

Y.D interaction

(e) Mineral $\mathrm{N}$ at harvest $0-30 \mathrm{~cm}$ where $\mathrm{N}$ applied at recommended rate

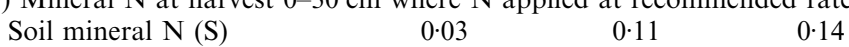

Mineralization rate $(\mathrm{M})$

Harvest yield (Y)
Duration of growth (D)

$\begin{array}{lll}0.18 & 0.09 & 0.05\end{array}$

23306

3900

38932

S.Y interaction

$0 \cdot 20$

M.Y interaction

Y.D interaction

$1.82 \quad 5 \cdot 36$

$5 \cdot 85$

$7 \cdot 23$

1.83

$4 \cdot 41$

23.9

1.67

(f) Mineral $\mathrm{N}$ at harvest 0-90 $\mathrm{cm}$ where $\mathrm{N}$ applied at recommended rate

Soil mineral N (S)

Mineralization rate $(\mathrm{M})$

Harvest yield (Y)

118

Duration of growth (D)

$0 \cdot 42$

853

117

S.Y interaction

496

848

$0.52 \quad 0.54$

0.09

846

$0 \cdot 10$

453

Table 4. (cont.)

\begin{tabular}{|c|c|c|c|c|c|}
\hline $0 \cdot 03$ & $*$ & $*$ & $4 \cdot 81$ & 6.51 & $4 \cdot 41$ \\
\hline 0.65 & $*$ & $*$ & $12 \cdot 2$ & $8 \cdot 21$ & 0.87 \\
\hline $7 \cdot 76$ & $*$ & $*$ & $16 \cdot 3$ & $17 \cdot 51$ & 3.98 \\
\hline 1600 & $*$ & $*$ & 1351 & 1203 & 1849 \\
\hline 0.09 & $*$ & $*$ & $0 \cdot 47$ & $0 \cdot 23$ & 2.79 \\
\hline $0 \cdot 74$ & $*$ & $*$ & 3.32 & $2 \cdot 29$ & 0.77 \\
\hline 1233 & $*$ & $*$ & 98.9 & 143 & 268 \\
\hline $0 \cdot 03$ & $0 \cdot 11$ & $0 \cdot 15$ & $0 \cdot 01$ & $0 \cdot 03$ & $0 \cdot 14$ \\
\hline $0 \cdot 11$ & $0 \cdot 12$ & 0.08 & $0 \cdot 10$ & $0 \cdot 07$ & 0.05 \\
\hline 18123 & 31364 & 32402 & 57703 & 75628 & 48834 \\
\hline $1 \cdot 35$ & $0 \cdot 50$ & $0 \cdot 68$ & $0 \cdot 21$ & $0 \cdot 23$ & $0 \cdot 46$ \\
\hline 0.72 & $5 \cdot 46$ & $7 \cdot 33$ & $0 \cdot 51$ & $3 \cdot 19$ & $8 \cdot 53$ \\
\hline $2 \cdot 76$ & $5 \cdot 20$ & $3 \cdot 32$ & $7 \cdot 56$ & 7.63 & 3.49 \\
\hline $88 \cdot 4$ & $34 \cdot 3$ & $59 \cdot 0$ & 179 & $54 \cdot 1$ & 58.8 \\
\hline $2 \cdot 54$ & $2 \cdot 03$ & 1.83 & 3.67 & 4.94 & 1.84 \\
\hline 118 & 115 & 115 & $97 \cdot 2$ & 113 & 116 \\
\hline $0 \cdot 44$ & $0 \cdot 54$ & $0 \cdot 89$ & 0.52 & $0 \cdot 72$ & $0 \cdot 72$ \\
\hline 845 & 853 & 849 & 1062 & 869 & 847 \\
\hline $0 \cdot 15$ & $0 \cdot 13$ & $0 \cdot 14$ & $0 \cdot 37$ & $0 \cdot 15$ & $0 \cdot 13$ \\
\hline 490 & 493 & 466 & 350 & 418 & 414 \\
\hline
\end{tabular}

* Indicates that no ratio could be calculated as the mean square for the denominator was zero. Ratios significant at the $0 \cdot 1 \%$ level are shown in bold. 

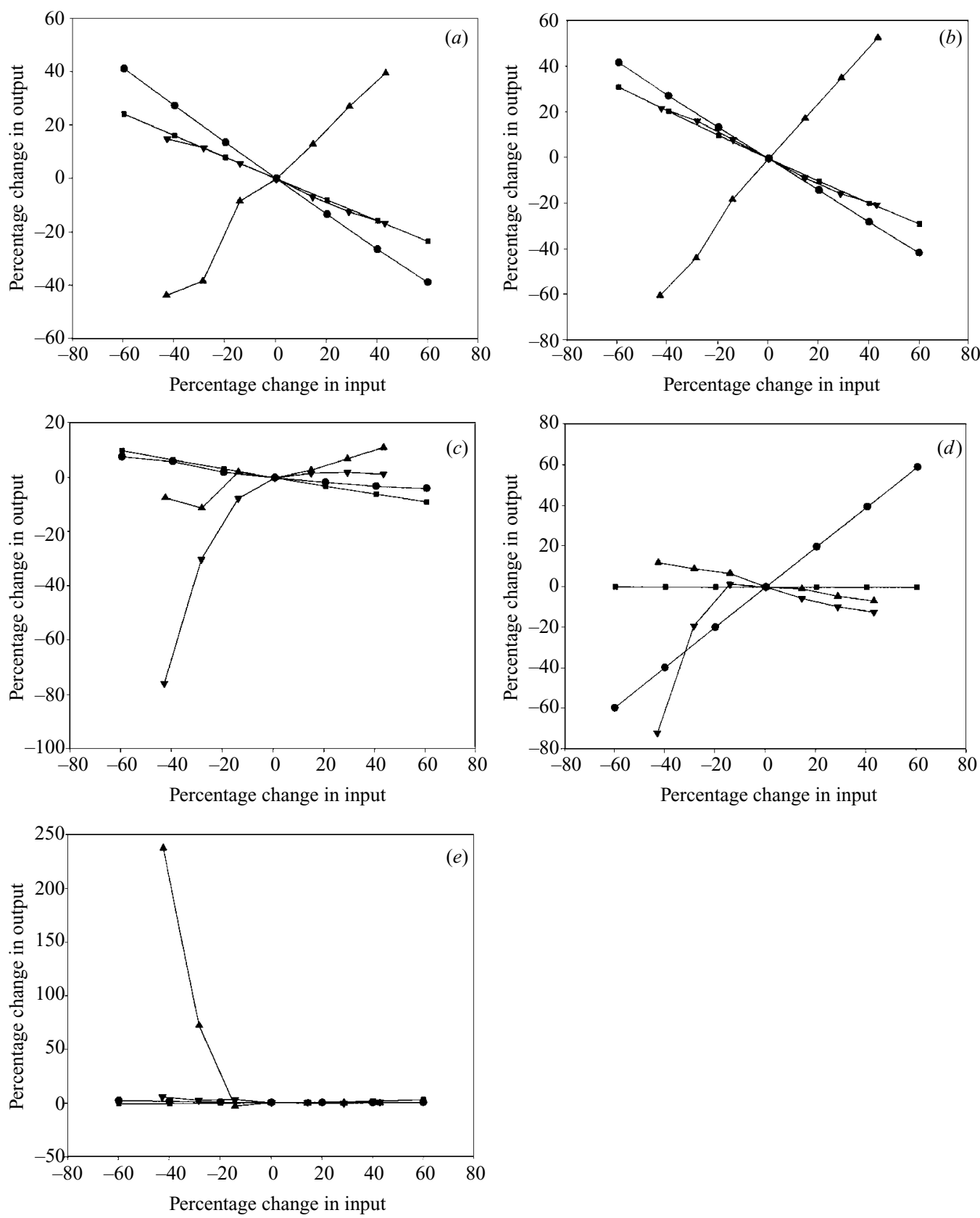

Fig. 2. Effects of variation in individual input factors on $(a)$ applied nitrogen to achieve $99 \%$ of maximum dry weight, for average rainfall on sandy loam soil, $(b)$ increase in dry weight at optimum applied $\mathrm{N}$ relative to that at zero applied $\mathrm{N}$, for average rainfall on sandy loam soil, $(c)$ the amount of $\mathrm{NO}_{3}-\mathrm{N}$ leached from $0-30 \mathrm{~cm}$, for high rainfall on sandy soil, $(d)$ the amount of $\mathrm{NO}_{3}-\mathrm{N}$ leached from 0-90 cm, for high rainfall on sandy soil, and (e) soil mineral $\mathrm{N}$ in $0-30 \mathrm{~cm}$ at harvest, for average rainfall on sandy loam soil. Effects shown for soil mineral $\mathrm{N}(\boldsymbol{O})$, mineralization rate ( $\boldsymbol{\square})$, yield expectation ( and crop duration $(\boldsymbol{\nabla})$. Mid-point values are given in Appendix A.

shown in Table 3, also indicating the degrees of freedom associated with each variance ratio.

Where output variables were sensitive to variation in the input factors, example responses were shown graphically, either as response curves in 'spider' diagrams (for main effects) or as three-dimensional 
(a)

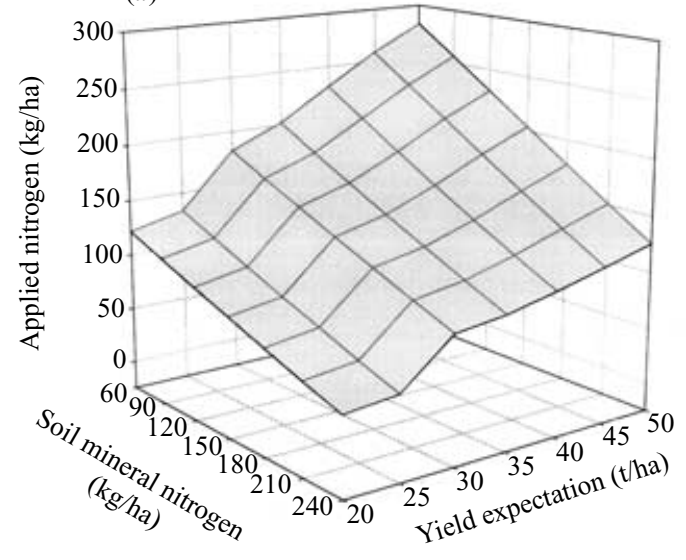

(c)

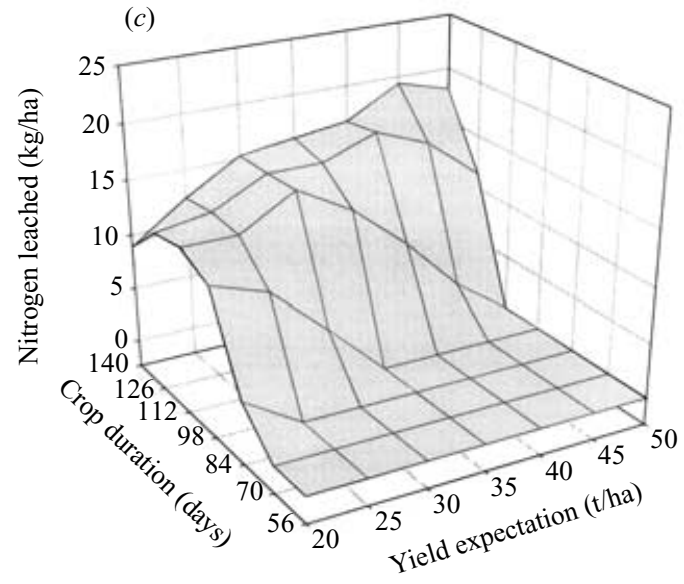

(e)

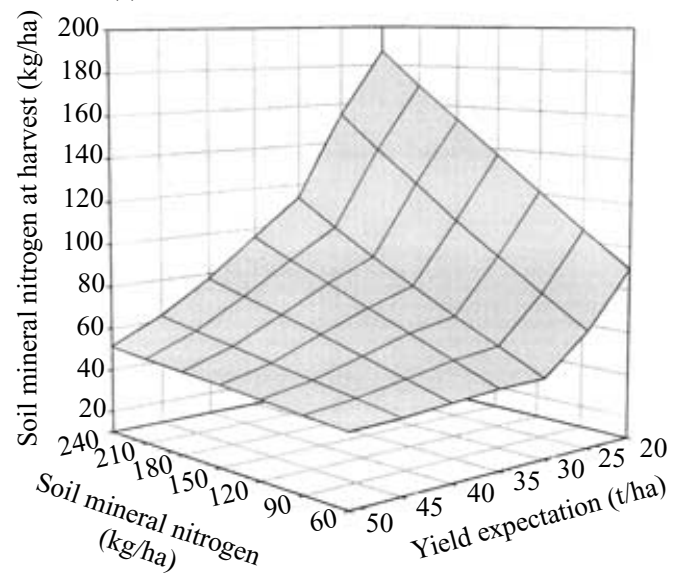

(b)
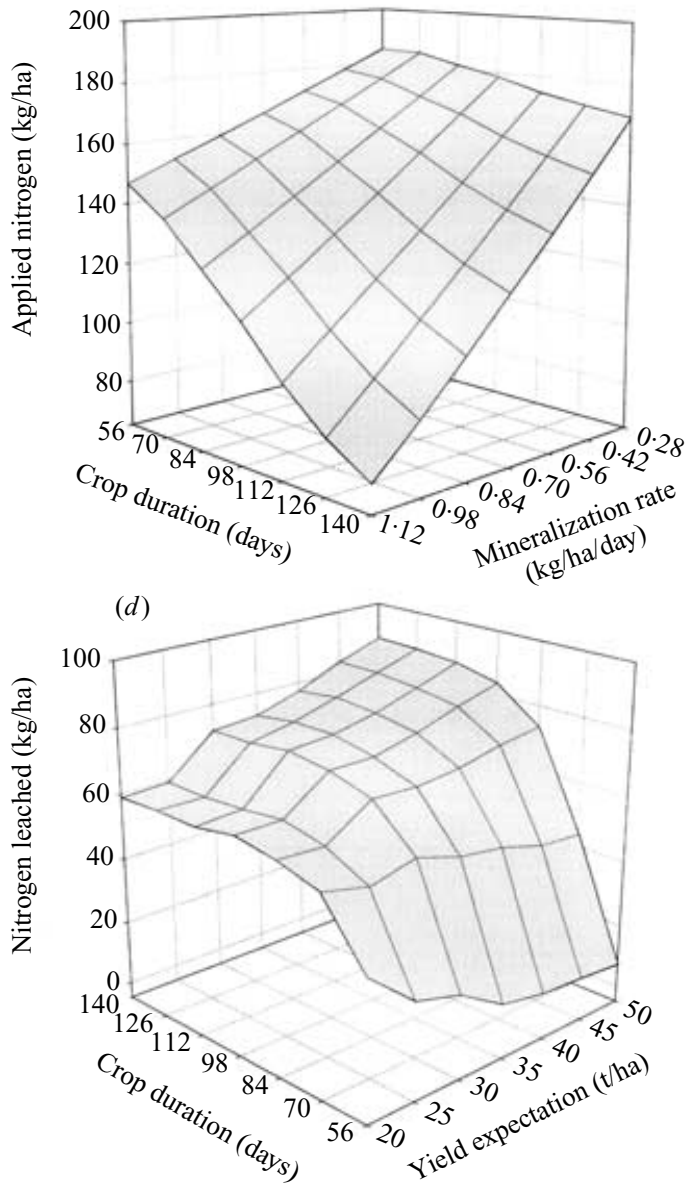

Fig. 3. Effects of joint variation of (a) soil mineral $\mathrm{N}$ and yield expectation on applied $\mathrm{N}$ to achieve $99 \%$ of maximum dry weight, for average rainfall on sandy loam soil, $(b)$ mineralization rate and crop duration on applied $\mathrm{N}$ to achieve $99 \%$ of maximum dry weight, for average rainfall on sandy loam soil, $(c)$ yield expectation and crop duration on the amount of $\mathrm{NO}_{3}$ $\mathrm{N}$ leached from $0-30 \mathrm{~cm}$, for average rainfall on sandy soil, $(d)$ yield expectation and crop duration on $\mathrm{NO}_{3}-\mathrm{N}_{\text {leached from }}$ $0-30 \mathrm{~cm}$, for high rainfall on sandy soil, and $(e)$ soil mineral $\mathrm{N}$ and yield expectation on soil mineral $\mathrm{N}$ in $0-90 \mathrm{~cm}$ at harvest, for average rainfall on sandy loam soil. 
response surfaces (for two- and three-factor interactions), together with tables showing the values at the extremes of the factor combinations.

Having assessed the sensitivity of the simulation model to variation in the important input parameters identified above, a second series of calculations was performed to determine the effects of incorrectly specifying the parameter values. For each combination of input factor levels, output variables were calculated, again by cubic interpolation, at the optimum level of applied $\mathrm{N}$ fertilizer predicted at the mid-point values of all four factors. This allowed the assessment of the effect of both under- and overestimating the values of each of the input factors. The resulting data were analysed using the same approach as described above, with response curves and surfaces constructed at the mid-point values of the other factors, rather than using mean values across the levels of the other factors as for the first set of data.

\section{RESULTS AND DISCUSSION}

\section{Nitrogen recommendations}

Predicted levels of applied fertilizer $\mathrm{N}$ required to achieve $99 \%$ of the maximum yield were around $145 \mathrm{~kg} / \mathrm{ha}$ at the mid-point of each factor in dry and average conditions with little effect of soil type (Appendix A). In wet conditions, soil type only had an influence on the lightest soils where it was estimated that around $160 \mathrm{~kg} / \mathrm{ha} \mathrm{N}$ was required at the midpoint of each factor (Appendix A). This suggested less efficient use of $\mathrm{N}$ on light soils because of leaching losses in wet conditions. Compared with MAFF fertilizer recommendations (MAFF 2000) these average rates of $\mathrm{N}$ application compare with more fertile, SNS index 3 or 4 conditions in which soils would typically supply around $101-160 \mathrm{~kg} / \mathrm{ha}$ from mineral $\mathrm{N}$ to $90 \mathrm{~cm}$ and mineralization from soil organic matter.

Individually, there were significant effects for all four input factors on the $\mathrm{N}$ recommendation to produce $99 \%$ of the maximum dry weight yield (Table $4 a$ ). The patterns of response to the factors were similar for all nine combinations of rainfall and soil type, as illustrated in Fig. $2 a$ for average rainfall on sandy loam soil. Where the response to a factor is almost linear (as seen for all four factors in Fig. 2a), the sum of squares associated with the term is almost entirely attributable to the linear contrast, a larger value indicating a steeper slope. As a consequence the relative sizes of the variance ratios give an indication of the relative importance of each input factor, a larger ratio generally indicating a greater response.

The greatest effect on $\mathrm{N}$ recommendation was caused by changes in yield expectation (Table $4 a$, Fig. $2 a$ ), with on average a change of $1 \%$ in $\mathrm{N}$ recommendation for each $1 \%$ change in yield expectation.
Table 5. $N$ recommendations for combinations of the soil mineral $N$ and yield expectation factors, at the 'corners' and centre of the parameter space

\begin{tabular}{llrrrrr}
\hline \hline \multicolumn{2}{c}{$\begin{array}{c}\text { Soil mineral N kg/ha } \\
\text { Yield expectation t/ha } \\
\text { Rainfall }\end{array}$} & $\begin{array}{r}150 \\
\text { Soil type }\end{array}$ & 60 & 60 & 240 & 240 \\
& & & & & \\
\hline Low & Sand & 145 & 121 & 285 & 39 & 127 \\
Low & Sandy loam & 145 & 122 & 285 & 45 & 128 \\
Low & Silt loam & 145 & 122 & 285 & 45 & 127 \\
Average & Sand & 144 & 120 & 282 & 38 & 126 \\
Average & Sandy loam & 145 & 122 & 283 & 44 & 126 \\
Average & Silt loam & 144 & 122 & 283 & 45 & 125 \\
High & Sand & 161 & 140 & 288 & 69 & 146 \\
High & Sandy loam & 149 & 124 & 285 & 54 & 134 \\
High & Silt loam & 146 & 122 & 284 & 49 & 130 \\
\hline \hline
\end{tabular}

Although the effect was not entirely linear, an increase in yield expectation did result in an increased $\mathrm{N}$ requirement. The non-linearity between reductions of 28 and $14 \%$ of marketable yield (corresponding to 25 and $30 \mathrm{t} / \mathrm{ha}$ yield) reflects the increased $\mathrm{N}$ uptake achieved at low yield levels due to the increased horizontal and vertical distribution of the root system. The other three factors all cause similar linear responses, with soil mineral $\mathrm{N}$ causing the greatest response (Fig. 2a). However, even large changes $( \pm 60 \%)$ in mineralization rate caused changes in $\mathrm{N}$ recommendation of less than $25 \%$. Increases in all three factors (soil mineral $\mathrm{N}$, mineralization rate and duration of growth) can be thought of as representing an increase in soil $\mathrm{N}$ availability. As the soil availability of $\mathrm{N}$ increased, the requirement for applied $\mathrm{N}$ decreased.

For all soil type/rainfall combinations, the only significant interaction effect was between soil mineral $\mathrm{N}$ and expected yield, though in all cases this interaction was considerably less important than any of the factor main effects (Table 4a). The pattern of this interaction was similar for all soil/rainfall combinations, and is illustrated in Fig. $3 a$ for average rainfall on sandy loam soil. The response to increasing soil mineral $\mathrm{N}$ is much greater for high yield expectation than where the yield expectation is low, whilst the response to increasing yield expectation is greater with less soil mineral N. Table 5 contains the $\mathrm{N}$ recommendations at the 'corners' and centre of the 'parameter space'. The maximum recommendation, required for low soil mineral $\mathrm{N}$ and high yield expectation, is almost identical for all nine soil type/rainfall combinations. The patterns for the low and average rainfall scenarios are also very similar, the only variation being in the $\mathrm{N}$ recommendation for high soil mineral $\mathrm{N}(240 \mathrm{~kg} / \mathrm{ha})$ and low yield expectation $(20 \mathrm{t} / \mathrm{ha})$, where the recommendation is lower for sand than for either of the other soil types. 
For the high rainfall scenarios $\mathrm{N}$ recommendations were generally higher than for the other rainfall scenarios, most notably for sandy soils.

The benefit of applying the recommended $\mathrm{N}$ level is represented by yield response, taken to be the difference between the yield at the 'optimum' level of applied $\mathrm{N}$ and that for zero applied $\mathrm{N}$. Analogous to the analysis of $\mathrm{N}$ recommendations, there were significant main effects of all four input factors on the yield response (Table $4 b$ ). Again, the greatest effect on this difference in yield response was caused by changes in yield expectation, with an increase in yield expectation resulting in an increase in achieved yield (Fig. 2b), as might be anticipated. Increases in each of the other three input factors (soil mineral $\mathrm{N}$, mineralization rate, crop duration), resulted in a decrease in yield response. The yield expectation factor affects the maximum achievable yield for a given set of parameters, whilst the other three input factors affect the soil availability of $\mathrm{N}$, and hence the yield achievable without applying fertilizer $\mathrm{N}$.

Many systems rely simply on the assessment of soil mineral $\mathrm{N}$ to form the basis of $\mathrm{N}$ recommendations (see, for example, MacKenzie \& Taureau (1997) and Geypens \& Vendendriessche (1996)). These systems rely on measurements taken at a single time, either before or after planting, taking no account of the effects of changing conditions, on both the distribution and amount of soil mineral $\mathrm{N}$ in the soil profile. Rahn et al. (1996a) has shown the importance of taking such redistribution of mineral $\mathrm{N}$ into account for brassica crops. In particular they showed that where $\mathrm{N}$ was located deeper in the soil profile, fresh fertilizer $\mathrm{N}$ needed to be applied to achieve maximum yields. Many of the recommendation systems referred to in the introduction require estimates of soil mineralization rate, but the WELL_N model was relatively insensitive to quite large changes in mineralization rate (Fig. $3 b$ ). The effects of mineralization rate were larger for long season crops, short season crops with even fourfold changes in mineralization rate only showing a $25 \%$ change in recommendation rate. In addition Greenwood et al. (1996) suggested that the main field to field variations in $\mathrm{N}$ supply for soil were as a result of incorporation of fresh crop residues rather than changes in mineralization of $\mathrm{N}$ from soil organic matter. The WELL_N simulation model is able to predict variations in the release of $\mathrm{N}$ from crop residue materials, and the subsequent redistribution of $\mathrm{N}$ caused by rainfall events. As a result, $\mathrm{N}$ recommendations provided by the model are more targeted to the availability of $\mathrm{N}$ in specific situations (Rahn et al. 1996b).

\section{Redistribution of nitrogen}

Leaching can reduce amounts of available $\mathrm{N}$ in the root zone of crops thereby reducing the efficiency of
$\mathrm{N}$ use, and hence increasing the amounts of $\mathrm{N}$ to be supplied by fertilizer. Using the simulation model it was calculated that more movement of $\mathrm{NO}_{3}-\mathrm{N}$ occurred on lighter soils in wetter seasons (Appendix A), but only small amounts $(<11 \mathrm{~kg} / \mathrm{ha})$ were calculated to have been moved below $90 \mathrm{~cm}$. Where leaching below $90 \mathrm{~cm}$ was indicated, the dominant effects were for soil mineral $\mathrm{N}$ and duration in growth (Table $4 c$ ): increases in both generally leading to increased levels of leaching.

Leaching below $30 \mathrm{~cm}$ would affect the availability of $\mathrm{N}$ to the shallow roots of young crops, but was not calculated on any soil given low rainfall, and only on sandy soils in average rainfall conditions. For this scenario, the main response was to crop duration (Table $4 d$, Fig. 2c). Higher levels of leaching were calculated for longer season crops, particularly for high yielding crops where nearly $20 \mathrm{~kg} / \mathrm{ha} \mathrm{N}$ was moved for a 140-day crop compared with less than $4 \mathrm{~kg} / \mathrm{ha} \mathrm{N}$ for a 98-day crop and no leaching for a 56day crop (Fig. 3c). This could be explained by the increased risk of leaching with the larger amounts of $\mathrm{N}$ needed for higher yields, being applied as a single dressing before crops grew away. Higher leaching levels were calculated for high rainfall on all soils, with simulations indicating up to $84 \mathrm{~kg} / \mathrm{ha} \mathrm{N}$ being leached for sandy soils (Fig. $3 d$ ). There were significant effects on leaching levels below $30 \mathrm{~cm}$ for all four factors on all three soils, with the exception of mineralization rate on silt loam soils (Table $4 d$ ).

On both sand and sandy loam soils, $\mathrm{NO}_{3}-\mathrm{N}$ leaching below $30 \mathrm{~cm}$ generally declined with both increasing soil mineral $\mathrm{N}$ and mineralization rate, whilst on silt loam soils there was little effect of mineralization rate and leaching increased with increased soil mineral $\mathrm{N}$. The minimal effect of varying mineralization rate on the amount of leaching below $30 \mathrm{~cm}$ can be explained in that the larger soil supplying capacity was matched by a lower requirement for applied fertilizer $\mathrm{N}$.

Leaching below $30 \mathrm{~cm}$ will affect the amount of $\mathrm{N}$ available to young crops, and similar effects have been both simulated and measured in field situations (Lord \& Bland 1991), and measured in undisturbed columns of light soil (Esala \& Leppänen 1998). Such movement of $\mathrm{N}$ out of the immediate rooting zone of young crops may require additional amounts of $\mathrm{N}$ to be applied to overcome initial shortages. However, it is also likely that the crops will subsequently recover some of the $\mathrm{N}$ leached below $30 \mathrm{~cm}$, when roots have been developed below this depth. Strategies such as splitting of fertilizer and the application of placed fertilizer by banding or as starter fertilizer (Stone 2000) may reduce the amounts of $\mathrm{N}$ lost by leaching. However the existing model requires further adaptation before it can be used to take account of either banded application of fertilizer or the use of starter fertilizers. 


\section{Potentially leachable soil mineral nitrogen at harvest}

Soil mineral $\mathrm{N}$ at harvest can be considered as an indication of the potential for environmental pollution through leaching during the following winter.

For all weather/soil type scenarios, the only significant main factor effect on mineral $\mathrm{N}$ at harvest in the $0-30 \mathrm{~cm}$ layer was due to yield expectation (Table 4e). Substantial levels of mineral $\mathrm{N}$ at harvest were simulated for low yield expectations (20 or $25 \mathrm{t} / \mathrm{ha}$ ) with no effect of yield expectation above these levels (Fig. 2e). A number of minor interactions were indicated, but even for the largest of these (the yield expectation by duration of growth interaction on average or high rainfall on sandy soils), the effect only appears as a minor modification of the main effect of yield expectation.

Both soil mineral $\mathrm{N}$ before planting and yield expectation had significant effects on soil mineral $\mathrm{N}$ at harvest in the 0-90 cm layer for all weather/soil type scenarios (Table $4 f$ ). Both effects, however, are modified by the effect of the other factor, so that the interaction between the two factors best illustrates the pattern of response (Fig. 3e). In general, as soil mineral $\mathrm{N}$ before planting increases, the level of soil mineral $\mathrm{N}$ at harvest increases, but with a larger response to soil mineral $\mathrm{N}$ before planting when the yield expectation is lower. Similarly, in general, an increase in yield expectation resulted in a decline in soil mineral $\mathrm{N}$ at harvest, with the greatest differences seen at high levels of soil mineral $\mathrm{N}$ before planting.

Soil mineral $\mathrm{N}$ left at harvest should be minimized to reduce the risks of subsequent leaching of $\mathrm{N}$ to the water table (Rice et al. 1995). The amount of soil mineral $\mathrm{N}$ in the top $30 \mathrm{~cm}$ provides some indication of the efficiency of the crops in using N. If yield levels were high, little mineral $\mathrm{N}$ was left at harvest and there was little effect of soil mineral $\mathrm{N}$ because $\mathrm{N}$ was used well by the crop. Where maximum yields were low, $\mathrm{N}$ was used inefficiently and where planting mineral $\mathrm{N}$ was higher than needed to supply the needs of the crop, mineral $\mathrm{N}$ levels at harvest were very high. Initial distribution of soil mineral $\mathrm{N}$ can also affect crop response (Rahn et al. 1996a). Decision support systems, such as WELL_N offer the opportunity to take account of the actual distribution of soil mineral $\mathrm{N}$ before planting (Rahn et al. 1996b). Where initial mineral $\mathrm{N}$ is distributed at lower layers in the soil profile WELL_N is able to allow for the increased risk of leaching during the growing season. Where $\mathrm{N}$ supply balances crop requirements, mineral $\mathrm{N}$ levels remaining at harvest are minimized (Prins et al. 1988, Davies \& Sylvester-Bradley 1995).

\section{The impact of incorrect nitrogen recommendations}

The sensitivity analysis described above has shown the dominant effects of soil mineral $\mathrm{N}$ at planting and yield expectation on both the recommended level of applied $\mathrm{N}$ and two key output variables. One of these, the yield response, relates to the culture of the crop, and the second, the amount of potentially leachable soil mineral $\mathrm{N}$ at harvest, relates to environmental issues. The impact of the application of incorrect fertilizer recommendations was assessed by simulating both yield achieved and soil mineral $\mathrm{N}$ at harvest for the range of input parameter values, but with the level of applied fertilizer fixed at that recommended at the mid-point values of all four input factors.

On the sandy loam soil with average rainfall, the recommendation for applied $\mathrm{N}$ at the mid-point values of all four input factors (Table 2) was $147 \mathrm{~kg} / \mathrm{ha}$, giving a yield within $99 \%$ of $35 \mathrm{t} / \mathrm{ha}$, and leaving $70 \mathrm{~kg} /$ ha soil mineral $\mathrm{N}(0-90 \mathrm{~cm})$ at harvest. The predicted losses in achieved yield and gains in soil mineral $\mathrm{N}(0-90 \mathrm{~cm})$ at harvest due to application of $\mathrm{N}$ at this level are shown for combinations of input factor values for yield expectation and soil mineral $\mathrm{N}$ before planting in Figs $4 a$ and $4 b$, respectively.

Reductions in achieved yield with $147 \mathrm{~kg} / \mathrm{ha} \mathrm{N}$ were confined to situations where either yield expectation was underestimated (true values $>35 \mathrm{t} / \mathrm{ha}$ ) or soil mineral $\mathrm{N}$ before planting was overestimated (true values $<150 \mathrm{~kg} / \mathrm{ha}$ ), or both (Fig. $4 a$ ). These situations coincided with those where the correct recommended applied $\mathrm{N}$ level exceeded that at the mid-point values of the input factors. Where soil mineral $\mathrm{N}$ before planting was underestimated (true values $>150 \mathrm{~kg} / \mathrm{ha}$ ), yield losses only occurred where yield expectation was badly underestimated. Similarly, where yield expectation was overestimated (true values $<35 \mathrm{t} / \mathrm{ha}$ ), yield losses only occurred where soil mineral $\mathrm{N}$ before planting was badly overestimated. The greatest yield loss occurred where yield expectation should have been $50 \mathrm{t} /$ ha (rather than $35 \mathrm{t} / \mathrm{ha}$ ) and soil mineral $\mathrm{N}$ before planting should have been $60 \mathrm{~kg} / \mathrm{ha}$ (rather than $150 \mathrm{~kg} / \mathrm{ha}$ ). The consequent reduction in applied $\mathrm{N}$ from $286 \mathrm{~kg} / \mathrm{ha}$ to $147 \mathrm{~kg} / \mathrm{ha}$ resulted in a yield loss of $7.9 \mathrm{t} /$ ha (about $20 \%$ of the potential yield). Where yield expectation was underestimated $(35 \mathrm{t} / \mathrm{ha}$ rather than $50 \mathrm{t} / \mathrm{ha}$ ) but soil mineral $\mathrm{N}$ before planting is correct, the reduction in applied $\mathrm{N}$ from $208 \mathrm{~kg} / \mathrm{ha}$ to $147 \mathrm{~kg} / \mathrm{ha}$ resulted in a yield loss of $2 \cdot 6 \mathrm{t} / \mathrm{ha}$. Similarly, where soil mineral $\mathrm{N}$ before planting was overestimated $(150 \mathrm{~kg} / \mathrm{ha}$ rather than $60 \mathrm{~kg} / \mathrm{ha})$, but yield expectation is correct, the reduction in applied $\mathrm{N}$ from $203 \mathrm{~kg} / \mathrm{ha}$ to $147 \mathrm{~kg} / \mathrm{ha}$ resulted in a yield loss of $2.9 \mathrm{t} / \mathrm{ha}$.

The slight increase in achieved yield where yield expectation was overestimated and soil mineral $\mathrm{N}$ before planting is underestimated is caused by more $\mathrm{N}$ being applied than would be correctly recommended and the achieved yield reaching the maximum value rather than $99 \%$ of the maximum. 


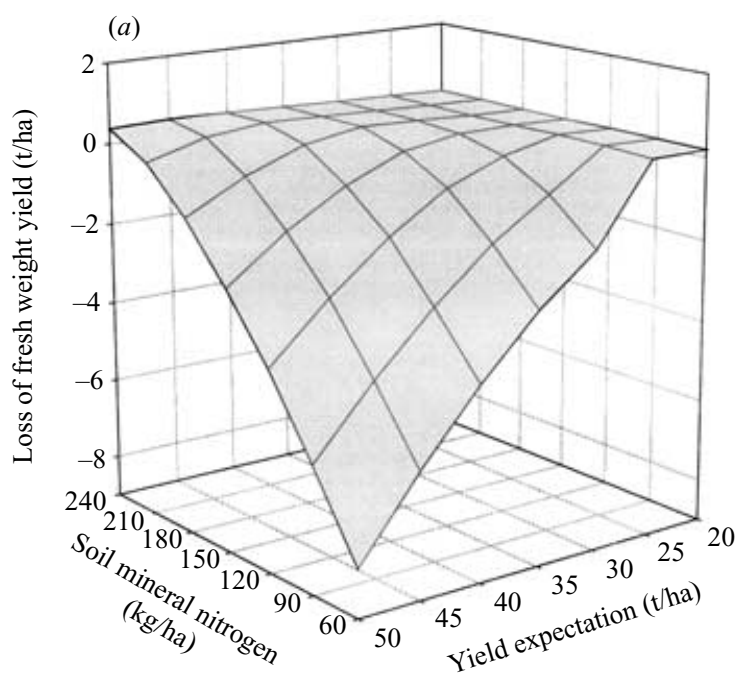

(b)

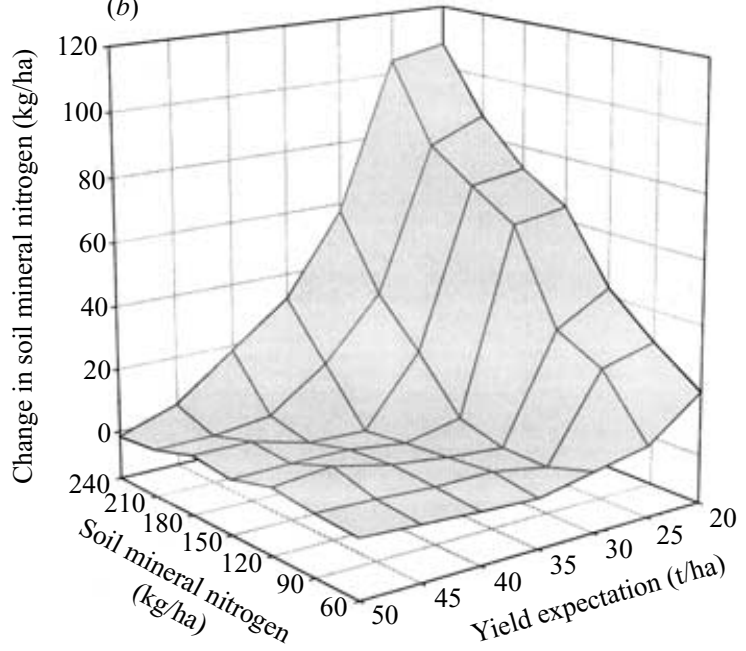

Fig. 4. The impact of incorrect values of soil mineral $\mathrm{N}$ and yield expectation on $(a)$ achieved fresh weight yield and $(b)$ soil mineral $\mathrm{N}$ at harvest in $0-90 \mathrm{~cm}$. Applied N $(147 \mathrm{~kg} / \mathrm{ha}$ $\mathrm{N})$ based on $150 \mathrm{~kg} /$ ha mineral $\mathrm{N}$, a yield expectation of $35 \mathrm{t} /$ ha for average rainfall, a crop duration of 98 days, and a mineralization rate of $0.70 \mathrm{~kg} / \mathrm{ha} /$ day $@ 15.9{ }^{\circ} \mathrm{C}$ on sandy loam soil.

Whilst overestimating yield expectation or underestimating soil mineral $\mathrm{N}$ before planting have relatively little impact on the achieved crop yield, these errors can have a substantial impact on the risk of environmental pollution, as measured by the increase in soil mineral $\mathrm{N}(0-90 \mathrm{~cm})$ at harvest (Fig. $4 b)$. Significant increases in soil mineral $\mathrm{N}$ at harvest only occurred where the correct recommended applied $\mathrm{N}$ level was significantly less than $147 \mathrm{~kg} / \mathrm{ha}$. The most dramatic increase was simulated where yield expectation should have been $20 \mathrm{t} /$ ha (rather than $35 \mathrm{t} / \mathrm{ha}$ ) and where soil mineral $\mathrm{N}$ before planting should have been $240 \mathrm{~kg} / \mathrm{ha}$ (rather than $150 \mathrm{~kg} / \mathrm{ha}$ ). The consequent increase in applied $\mathrm{N}$ from $37 \mathrm{~kg} / \mathrm{ha}$ to $147 \mathrm{~kg} /$ ha resulted in an additional $108 \mathrm{~kg} / \mathrm{ha}$ soil mineral $\mathrm{N}$ remaining at harvest (leaving a total of $285 \mathrm{~kg} /$ ha potentially leachable $\mathrm{N}$ ).

The impact of underestimating yield expectation or overestimating soil mineral $\mathrm{N}$ before planting was environmentally friendly, with little additional soil mineral $\mathrm{N}$ remaining at harvest, though with the associated yield losses described above.

\section{PRACTICAL IMPLICATIONS}

WELL_N provides a dynamic system for providing $\mathrm{N}$ recommendations for cauliflower crops. It is sensitive to those factors which are easily measurable by the grower. Errors in measurements of mineralization rate make little difference to fertilizer recommendations especially for short season crops. The model is highly sensitive to measurements of soil mineral $\mathrm{N}$ before planting and estimation of yield expectation. Measurements of soil mineral $\mathrm{N}$ before planting are relatively easily made, and growers often subjectively estimate yield expectation based on previous yield performance in the field. However, there is little in the literature to support an objective assessment of yield expectation, except in limited circumstances (Campbell et al. 1997).

The modelling approach has also enabled possible management strategies for the reduction of nitrate leaching from crops whilst maintaining production to be quantified. For example it would be an advantage to grow higher-yielding, faster-growing crops. Even though such crops have a larger fertilizer requirement they do deplete soil mineral $\mathrm{N}$ to a lower level and, providing that the residues of crop are well managed, this should reduce the risk of leaching (Rahn et al. 1996a). It would seem to be important to choose crop parameters that encourage a more complete uptake of $\mathrm{N}$ particularly in wet seasons. Significant loss of mineral $\mathrm{N}$ can occur from the rooting zone of shallow rooted crops. Strategies to target or split applications of $\mathrm{N}$ application to reduce $\mathrm{N}$ losses would be beneficial. From a leaching point of view it would also be useful to consider closer row spacing to ensure more complete exploration of the soil surface.

Financial support from the UK Ministry of Agriculture, Fisheries and Food for strategic research and Horticultural Development Council for the development work is greatly appreciated. 
Appendix A. Mean responses at the mid-points of the input factors for each of the soil-type by weather (rainfall) combinations: DSA, dry sand; DSAL, dry sandy loam; DSIL, dry silt loam; ASA, average sand; ASAL, average sandy loam; ASIL, average silt loam; WSA, wet sand; WSAL, wet sandy loam; WSIL, wet silt loam

\begin{tabular}{|c|c|c|c|c|c|c|c|c|c|}
\hline & DSA & DSAL & DSIL & ASA & ASAL & ASIL & WSA & WSAL & WSIL \\
\hline \multicolumn{10}{|l|}{ Soil mineral $\mathrm{N}$} \\
\hline $\mathrm{N}$ requirement for $99 \%$ yield & 143 & 144 & 144 & 142 & 143 & 143 & 159 & 148 & 145 \\
\hline Achieved yield at applied $\mathrm{N}$ & $5 \cdot 3$ & $5 \cdot 3$ & $5 \cdot 3$ & $5 \cdot 3$ & $5 \cdot 3$ & $5 \cdot 3$ & $5 \cdot 3$ & $5 \cdot 3$ & $5 \cdot 3$ \\
\hline Yield response & $2 \cdot 3$ & $2 \cdot 5$ & $2 \cdot 5$ & $2 \cdot 3$ & $2 \cdot 4$ & $2 \cdot 5$ & $2 \cdot 6$ & $2 \cdot 6$ & $2 \cdot 6$ \\
\hline $\mathrm{N}$ uptake at applied $\mathrm{N}$ & 205 & 205 & 205 & 205 & 205 & 205 & 207 & 206 & 206 \\
\hline $\mathrm{N}$ leached below $30 \mathrm{~cm}$ & 0 & 0 & 0 & 6 & 0 & 0 & 60 & 20 & 5 \\
\hline $\mathrm{N}$ leached below $90 \mathrm{~cm}$ & 0 & 0 & 0 & 0 & 0 & 0 & 11 & 4 & 2 \\
\hline Mineral $\mathrm{N}$ at harvest in $0-30 \mathrm{~cm}$ & 20 & 20 & 20 & 20 & 20 & 20 & 19 & 19 & 20 \\
\hline Mineral $\mathrm{N}$ at harvest in $0-90 \mathrm{~cm}$ & 79 & 79 & 79 & 75 & 79 & 79 & 82 & 80 & 79 \\
\hline \multicolumn{10}{|l|}{ Mineralization rate } \\
\hline $\mathrm{N}$ requirement for $99 \%$ yield & 143 & 144 & 144 & 143 & 143 & 143 & 160 & 149 & 146 \\
\hline Achieved yield at applied $\mathrm{N}$ & $5 \cdot 3$ & $5 \cdot 3$ & $5 \cdot 3$ & $5 \cdot 3$ & $5 \cdot 3$ & $5 \cdot 3$ & $5 \cdot 3$ & $5 \cdot 3$ & $5 \cdot 3$ \\
\hline Yield response & $2 \cdot 3$ & $2 \cdot 5$ & $2 \cdot 5$ & $2 \cdot 3$ & $2 \cdot 4$ & $2 \cdot 5$ & $2 \cdot 6$ & $2 \cdot 6$ & $2 \cdot 6$ \\
\hline $\mathrm{N}$ uptake at applied $\mathrm{N}$ & 205 & 205 & 205 & 205 & 206 & 206 & 207 & 206 & 206 \\
\hline $\mathrm{N}$ leached below $30 \mathrm{~cm}$ & 0 & 0 & 0 & 6 & 0 & 0 & 61 & 20 & 5 \\
\hline $\mathrm{N}$ leached below $90 \mathrm{~cm}$ & 0 & 0 & 0 & 0 & 0 & 0 & 11 & 4 & 2 \\
\hline Mineral $\mathrm{N}$ at harvest in $0-30 \mathrm{~cm}$ & 20 & 20 & 20 & 20 & 20 & 20 & 19 & 19 & 20 \\
\hline Mineral $\mathrm{N}$ at harvest in $0-90 \mathrm{~cm}$ & 79 & 80 & 80 & 79 & 79 & 79 & 82 & 80 & 80 \\
\hline \multicolumn{10}{|l|}{ Harvest yield } \\
\hline $\mathrm{N}$ requirement for $99 \%$ yield & 146 & 146 & 146 & 146 & 146 & 146 & 162 & 151 & 147 \\
\hline Achieved yield at applied $\mathrm{N}$ & $5 \cdot 3$ & $5 \cdot 3$ & $5 \cdot 3$ & $5 \cdot 3$ & $5 \cdot 3$ & $5 \cdot 3$ & $5 \cdot 3$ & $5 \cdot 3$ & $5 \cdot 3$ \\
\hline Yield response & $2 \cdot 4$ & $2 \cdot 5$ & $2 \cdot 6$ & $2 \cdot 4$ & $2 \cdot 5$ & $2 \cdot 5$ & $2 \cdot 7$ & $2 \cdot 7$ & $2 \cdot 6$ \\
\hline $\mathrm{N}$ uptake at applied $\mathrm{N}$ & 205 & 205 & 205 & 206 & 206 & 206 & 209 & 206 & 206 \\
\hline $\mathrm{N}$ leached below $30 \mathrm{~cm}$ & 0 & 0 & 0 & 6 & 0 & 0 & 61 & 20 & 5 \\
\hline $\mathrm{N}$ leached below $90 \mathrm{~cm}$ & 0 & 0 & 0 & 0 & 0 & 0 & 11 & 4 & 2 \\
\hline Mineral $\mathrm{N}$ at harvest in $0-30 \mathrm{~cm}$ & 14 & 14 & 14 & 14 & 14 & 14 & 14 & 14 & 14 \\
\hline Mineral $\mathrm{N}$ at harvest in $0-90 \mathrm{~cm}$ & 71 & 71 & 71 & 71 & 71 & 71 & 72 & 71 & 71 \\
\hline \multicolumn{10}{|l|}{ Duration of growth } \\
\hline $\mathrm{N}$ requirement for $99 \%$ yield & 144 & 145 & 145 & 144 & 144 & 144 & 164 & 150 & 146 \\
\hline Achieved yield at applied $\mathrm{N}$ & $5 \cdot 3$ & $5 \cdot 3$ & $5 \cdot 3$ & $5 \cdot 3$ & $5 \cdot 3$ & $5 \cdot 3$ & $5 \cdot 3$ & $5 \cdot 3$ & $5 \cdot 3$ \\
\hline Yield response & $2 \cdot 3$ & $2 \cdot 5$ & $2 \cdot 5$ & $2 \cdot 3$ & $2 \cdot 4$ & $2 \cdot 5$ & $2 \cdot 6$ & $2 \cdot 6$ & $2 \cdot 6$ \\
\hline $\mathrm{N}$ uptake at applied $\mathrm{N}$ & 205 & 205 & 205 & 206 & 206 & 206 & 208 & 206 & 206 \\
\hline $\mathrm{N}$ leached below $30 \mathrm{~cm}$ & 0 & 0 & 0 & 4 & 0 & 0 & 72 & 25 & 6 \\
\hline $\mathrm{N}$ leached below $90 \mathrm{~cm}$ & 0 & 0 & 0 & 0 & 0 & 0 & 13 & 6 & 3 \\
\hline Mineral $\mathrm{N}$ at harvest in $0-30 \mathrm{~cm}$ & 20 & 20 & 20 & 19 & 20 & 20 & 19 & 19 & 19 \\
\hline Mineral $\mathrm{N}$ at harvest in $0-90 \mathrm{~cm}$ & 79 & 79 & 79 & 78 & 79 & 79 & 83 & 80 & 79 \\
\hline
\end{tabular}

\section{REFERENCES}

BURNS, I. G. (1974). A model for predicting the redistribution of salts applied to fallow soils after excess rainfall evaporation. Journal of Soil Science 25, 165-168.

Burns, I. G., Rahn, C. R., Greenwood, D. J., Draycott, A. \& Richardson, A. S. (1997). A user friendly decision support system for adjusting $\mathrm{N}$ fertilizer requirements to local conditions. In Proceedings of a Conference on Managing Soil Fertility for Intensive Vegetable Production Systems in Asia, 4-10 November 1996. Taiwan: AVRDC, pp. 314-324.

Campbell, C. A., Selles, F., Zentner, R. P., McConkey, B. G., Brandt, S. A. \& McKenzie, R. C. (1997). Regression model for predicting yield of hard red spring wheat grown on stubble in semiarid prairie. Canadian Journal of Plant Science 77, 43-52.

Davies, D. B. \& Sylvester-Bradley, R. (1995). The contribution of fertiliser nitrogen to leachable nitrogen in the UK: A review. Journal of the Science of Food and Agriculture 68, 399-406.

EsALA, M. \& LePPÄNEN, A. (1998). Leaching of 15N-labeled fertilizer nitrate in undisturbed soil columns after simulated heavy rainfall. Communications in Soil Science and Plant Analysis 29, 1221-1238.

EveraARTS, A. P. (1994). Nitrogen fertilization and head rot in broccoli. Netherlands Journal of Agricultural Science 42, 195-201. 
FinK, M. \& ScharpF, H.-C. (1993). N Expert - A decision support system for vegetable fertilization in the field. Acta Horiculturae 339, 67-74.

Genstat 5 Committee (1993). Genstat 5 Release 3 Reference Manual. Oxford, UK: Clarendon Press.

Geypens, M. \& VendenRIESSChe, H. (1996). Advisory systems for nitrogen fertiliser recommendations. Plant and Soil 181, 31-38.

Greenwood, D. J. \& Draycott, A. (1989). Experimental validation of an $\mathrm{N}$-response model for widely different crops. Fertilizer Research 18, 153-174.

Greenwood, D. J., Gerwitz, A., Stone, D. A. \& Barnes, A. (1982). Root development of vegetable crops. Plant and Soil 68, 75-96.

Greenwood, D. J., Neeteson, J. J. \& Draycott, A. (1986). Quantitative relationships for the dependence of growth rate of arable crops on their nitrogen content, dry weight and aerial environment. Plant and Soil 91, 281-301.

Greenwood, D. J., Verstraeten, L. M. J. \& Draycott, A. (1987). Response of winter wheat to N-fertilizer: Quantitative relations for components of growth. Fertilizer Research 12, 119-137.

Greenwood, D. J., Kubo, K., Burns, I. G. \& Draycott, A. (1989). Apparent recovery of fertilizer $\mathrm{N}$ by vegetable crops. Soil Science and Plant Nutrition 35, 367-381.

Greenwood, D. J., Stone, D. A. \& Draycott, A. (1990). Weather, nitrogen-supply and growth rate of field vegetables. Plant and Soil 124, 297-301.

Greenwood, D. J., Gastal, F., Lemaire, G., Draycott, A., Millard, P. \& Neeteson, J. J. (1991). Growth rate and $\% \mathrm{~N}$ of field grown crops: theory and experiments. Annals of Botany 67, 181-190.

Greenwood, D. J., Neeteson, J. J., Draycott, A., Wijnen, G. \& Stone, D. A. (1992). Measurement and simulation of the effects of $\mathrm{N}$-fertilizer on growth, plant composition and distribution of soil mineral- $\mathrm{N}$ in nationwide onion experiments. Fertilizer Research 31, 305-318.

Greenwood, D. G., Rahn, C. R., Draycott, A. \& PATERSON, C. (1996). Modelling and measurement of the effects of fertilizer- $\mathrm{N}$ and crop residue incorporation on $\mathrm{N}$-dynamics in vegetable cropping. Soil Use and Management 12, 13-24.

Johnson, L. W. \& RiEss, R. D. (1982). Numerical Analysis (2nd edition) - Section 5.2.6. Reading, MA: AddisonWesley.

Lorenz, H. P., Schlaghecken, J., Engl, G., Maync, A., ZIEGLER, J. \& STROHMEYER, K. (1989). Kulturbegleitendes Nmin sollwert (KNS) - System. Mainz: Ministerium für Landwirtschaft, Weinbau und Forsten.

LORD, E. I. \& BLAND, G. (1991). Leaching of spring-applied fertilizer nitrogen: measurement and simulation. Soil Use and Management 7, 110-114.

Ministry for Agriculture, FoOd AND Fisheries (2000). Fertilizer Recommendations Seventh Edition, Reference Book 209. London: HMSO.

MacKenzie, G. H. \& Taureau, J. C. (1997). Recommendation systems for nitrogen - A review. Paper read before the Fertiliser Society of London on 11 December 1997. Proceedings No 403, The Fertilizer Society, pp. 1-51.

McKay, M. D., Conover, W. J. \& Beckman, R. J. (1979). A comparison of three methods for selecting values of input variables in the analysis of output from a computer code. Technometrics 21, 239-245.

Neeteson, J. J., Greenwood, D. J. \& Draycott, A. (1987). A dynamic model to predict yield and optimum nitrogen fertiliser application rate for potatoes. Paper read before the Fertiliser Society of London on 10 December 1987. Proceedings No 262, The Fertiliser Society, pp. 1-29.

Prins, W. H., Dilz, K. \& Neeteson, J. J. (1988). Current recommendations for nitrogen fertilisation within the EEC in relation to nitrate leaching. Proceedings No 276, The Fertiliser Society of London, UK, pp. 3-27.

Rahn, C. R., Paterson, C. D. \& Vaidyanathan, L. V. V. (1993). Improving the use of nitrogen in brassica rotations. Acta Horticulturae 339, 207-218.

Rahn, C. R., Paterson, C. D., Willison, T. \& Lillywhite, R. D. (1996a). The fate of nitrogen from brassica crop residues in intensive cropping rotations. In Nitrogen Supply and Nitrogen Fixation of Crops for Cool and Wet Climates. Proceedings of a COST 814 Workshop held at the Norwegian Crop Research Institute (Planteforsk) Holt Research Centre, Tromso, 7-9 September 1995 (Ed. R. Samuelsen et al.), pp. 219-226. Luxembourg: Office of Official Publications of the European Communities.

Rahn, C. R., Greenwood, D. J. \& Draycott, A. (1996b). Prediction of nitrogen fertiliser requirement with HRI WELL_N Computer Model. In Proceedings of 8th Nitrogen Workshop, Ghent, 5-8 September 1994. In Progress in Nitrogen Cycling Studies, pp. 255-258. Dordrecht: Kluwer.

Rice, C. W., Havilin, J. L. \& Schepers, J. S. (1995). Rational nitrogen fertilization in intensive cropping systems. Fertilizer Research 42, 89-97.

Riley, H. \& GutTormsen, G. (1993). N requirements of cabbage crops grown in contrasting soils. I: Field trials. Norwegian Journal of Agricultural Sciences 7, 275-291.

Riley, H. \& GutTormsen, G. (1994). N requirements of cabbage crops grown on contrasting soils in southern Norway. II. Model predictions. Norwegian Journal of Agricultural Sciences 8, 99-113.

SHEPHERD, M. A. (1993). Measurement of soil mineral nitrogen to predict the response of winter wheat to fertiliser nitrogen after application of organic manures or after ploughed - out grass. Journal of Agricultural Science, Cambridge 121, 223-231.

Sokal, R. R. \& Rohlf, F. J. (1995). Biometry: The Principles and Practice of Statistics in Biological Research (3rd Edition) - Section 16.5. New York, USA: W. H. Freeman \& Co.

Stone, D. A. (2000). The effects of starter fertilizers on the growth and nitrogen use efficiency of onion and lettuce. Soil Use and Management 16, 42-48.

Sutherland, R. A., Wright, C. C., Verstraeten, L. M. J. \& Greenwood, D. J. (1986). The deficiency of the 'economic optimum' application for evaluating models which predict crop yield response to nitrogen fertiliser. Fertilizer Research 10, 251-262.

VAn Veen, J. A. \& Frissel, D. E. (1981). Simulation model of the behaviour of $\mathrm{N}$ in soil. In Simulation of Nitrogen Behaviour of Soil Plant Systems (Eds M. J. Frissel \& J. A. Van Veen), pp. 126-144. Wageningen: Centre for Agricultural Publishing and Documentation. 